\title{
IDENTIFIKASI Salmonella spp. PADA FESES SAPI PERAH DI DUSUN JUDEG DESA BABADAN, KEDIRI
}

\section{IDENTIFICATION OF Salmonella spp. ON FECES OF DAIRY COW IN JUDEG HAMLET, BABADAN VILLAGE, KEDIRI}

\author{
Mastuti Widianingsih ${ }^{1}$, Erly Novita Dewi ${ }^{2}$ \\ ${ }^{1,2}$ Institut Ilmu Kesehatan Bhakti Wiyata, Kediri, Indonesia \\ Jalan Wakhid Hasyim No. 65, Kediri, Jawa Timur, 64114 \\ Email korespondensi : widianingsihmastuti910224@gmail.com
}

\begin{abstract}
ABSTRAK
Selain menghasilkan daging dan susu, sapi perah juga mengekskresikan kotoran padat (feses) dan kotoran cair (urine). Feses dapat menjadi agen penyebaran Salmonella spp. yang mengakibatkan salmonellosis. Tujuan penelitian ini adalah mengidentifikasi Salmonella spp. pada feses sapi perah di Dusun Judeg, Desa Babadan, Kediri. Penelitian menggunakan 25 sampel feses sapi perah. Sampel diinokulasikan pada Selenite Broth, kemudian diinokulasi pada Salmonella Shigella Agar (SSA), dilanjutkan pewarnaan Gram untuk mendeteksi jenis bakteri. Uji biokimia reaksi dilakukan pada hari ke-3 untuk membedakan golongan Enterobacter. Hasil penelitian menunjukkan 52\% feses sapi perah di Dusun Judeg, Desa Babadan, Kecamatan Ngancar, Kediri positif terkontaminasi Salmonella spp.
\end{abstract}

\section{Kata kunci : Sapi, Feses, Salmonella spp.}

\begin{abstract}
In addition to producing meat and milk, dairy cows also excret of solid waste (feces) and liquid (urine). Feces can be a spreading agent of Salmonella spp. That caused of salmonellosis. The purpose of this research was identification Salmonella spp. on feces of dairy cow in Judeg Hamlet, Babadan Village, Ngancar District, Kediri. The research design used 25 samples. The samples were inoculated on Selenite Broth, then the inoculation to Salmonella Shigella Agar (SSA), and next the Gram staining to detect the type of bacteria. The test of biochemical reaction was performed on day 3 to differentiate the Enterobacter class. The results showed that 52\% feces of dairy cow in Judeg Hamlet, Babadan Village, Ngancar District, Kediri positive contaminated of Salmonella spp.
\end{abstract}

Keyword: Cow, feces, Salmonella spp.

\section{PENDAHULUAN}

Sapi adalah jenis hewan ternak yang memenuhi sekitar 50\% kebutuhan daging di dunia, 95\% kebutuhan susu, dan $85 \%$ kebutuhan kulit. Sistem pengolahan dan pemeliharaan sapi sangat menentukan keberhasilan suatu usaha peternakan, misalnya saja pengolah hasil ekskresi. Salah satu jenis sapi, seperti sapi perah mengeluarkan ekskresi berupa kotoran padat (feses) dan kotoran cair (urine). Feses sapi perah sama halnya feses dari ternak lain yang dapat berpotensi mencemari lingkungan bila tidak dikelola dengan baik. Feses sapi perah mengandung sejumlah mikroba diantaranya protozoa, fungi, dan bakteri. Bakteri yang terdapat dalam saluran pencernaan ternak ruminansia diantaranya Lactobacillus sp., Escherichia, Eubacterium, Propionibacterium, Streptococcus, bacteriodes, Butyvibrio, Selenomonas, Clostridium, dan Metanobacterium, termasuk didalamnya kelompok bakteri patogen (Hidayati dkk., 2013).

Bakteri patogen adalah bakteri yang mampu menyebabkan penyakit. Salah satunya adalah Salmonella spp. yang menyebabkan penyakit salmonellosis. Kontaminasi produk olahan seperti susu dapat disebabkan oleh Salmonella spp. (Oscar, 2009). Salmonella spp. adalah bakteri berbentuk batang, tidak berspora, pada pewarnaan Gram bersifat negatif Gram, ukuran 1-3,5 x 0,5-0,8 $\mu \mathrm{m}$, besar koloni ratarata 2-4 $\mathrm{mm}$, mempunyai flagel peritrik kecuali Salmonella pullorum dan Salmonella gallinarum (Staf Pengajar Fakultas Kedokteran UI, 2010).

Hewan yang menderita salmonellosis dapat menjadi pembawa (carrier) yang menetap (persisten). Selain terdapat pada feses, Salmonella spp. juga dapat diisolasi dari tanah, air, dan limbah yang tercemar dengan material feses penderita salmonelosis (Ray, 2001). Salmonella spp. dapat menimbulkan berbagai macam manifestasi penyakit baik pada hewan ataupun manusia. Salmonella spp. akan berkembangbiak di dalam alat pencernaan penderita, sehingga terjadi radang usus (enteritis). Radang usus serta infeksi lamina propria akibat infeksi Salmonella spp. dapat menimbulkan diare akut (Cita, 2011). Selain itu, umumnya pada manusia, infeksi Salmonella spp. dapat menyebabkan demam enterik serta gastroenteritis. Penyebaran Salmonella spp. sendiri dapat terjadi 
melalui feses penderita salmonellosis yang akan mengekresikan bakteri 3-4 bulan setelah sembuh dari sakit (Direktorat Jendral Peternakan, 2014).

Umumnya sebelum susu diperah, sapi dimandikan terlebih dahulu. Air yang digunakan untuk memandikan sapi dimungkinkan telah terkontaminasi oleh Salmonella spp. yang berasal dari feses sapi perah. Cara pemerahan, pengelolaan ternak yang tidak sempurna, dan kebersihan kandang merupakan sumber kontaminan yang potensial. Identifikasi Salmonella spp. pada feses sapi perah di Dusun Judeg, Desa Babadan, Kediri penting dilakukan untuk meminimalisir penularan salmonellosis. Hal tersebut dikarenakan feses sapi perah merupakan agen penularan Salmonella spp. yang sangat cepat terhadap susu serta produk lainnya baik secara langsung maupun secara tidak langsung.

\section{METODE}

Penelitian ini dilakukan di laboratorium Bakteriologi Institut IImu Kesehatan Bhakti Wiyata Kediri pada bulan Maret 2017. Variabel bebas (independent) dalam penelitian ini adalah feses sapi perah di Dusun Judeg, Desa Babadan, Kediri. Variabel terikat (dependent) adalah Salmonella spp. Sampel yang digunakan sebanyak 25 sampel feses sapi perah.

\section{Alat dan Bahan}

\section{HASIL DAN PEMBAHASAN}

Peternakan sapi perah merupakan salah satu usaha di bidang peternakan yang memiliki peran strategis dalam memenuhi kebutuhan pangan yang terus meningkat, peningkatan pendapatan penduduk, dan peningkatan perekonomian nasional. Selain menghasilkan susu dan daging, sapi perah juga menghasilkan feses dan urine sebagai limbah. Limbah padat berupa feses jumlahnya setiap hari berkisar 5$10 \%$ dari bobot badan. Limbah tersebut apabila tidak diolah akan menjadi sumber cemaran bagi lingkungan,
Alat yang digunakan meliputi swab steril, tabung reaksi, tabung Khan, beacker glass, pipet Pasteur, pipet ukur $10 \mathrm{ml}$, neraca, kertas perkamen, erlenmeyer, spatel, autoclave, oven, inkase, rak tabung, plate, ose bulat dan ose jarum, object glass, staining jar, mikroskop binokular, inkubator, kapas, kaki tiga, asbes, dan lampu spirtus. Bahan yang digunakan meliputi feses sapi perah, media pemupuk Selenit Broth, dan media selektif Salmonella Shigella Agar (SSA).

\section{Pengambilan sampel feses sapi perah}

Sampel feses sapi perah diambil secara steril kemudian dimasukkan dalam pot sampel. Sampel selanjutnya di-swab dengan menggunakan cotton swab kemudian dimasukkan dalam tabung yang telah berisi media PZ.

\section{Pembiakan bakteri pada Salmonella Shigella Agar (SSA)}

Sebelum dibiakan pada SSA, sampel feses ditanam pada media transpot (Selenite Broth). Sampel digoreskan pada permukaan SSA secara zig-zag menggunakan swab steril dan diinkubasi pada suhu $37^{\circ} \mathrm{C}$ selama 24 jam. Koloni pada media SSA yang berwarna hitam (reduksi tellurite positif) menunjukkan Salmonella spp.

dikarenakan dalam feses mengandung sejumlah mikroba diantaranya protozoa, fungi, dan bakteri. Bakteri yang terdapat dalam saluran pencernaan ternak ruminansia salah satunya Salmonella spp. (Hidayati, 2010).

Pada penelitian ini dilakukan pengujian 25 sampel yang diduga terkontaminasi Salmonella spp. Hasil penelitian menunjukkan bahwa 13 sampel positif Salmonella spp. dengan persentase hasil 52\% (Tabel 1; Gambar 1). Hal tersebut ditunjukkan dengan koloni berwarna hitam pada media SSA.

Tabel 1. Hasil inokulasi pada media SSA

\begin{tabular}{|c|c|c|c|}
\hline Kode Sampel & Warna Koloni & Reduksi Tellurite & Keterangan \\
\hline 1 & Hitam & Positif & Salmonella spp. \\
\hline 2 & Hitam & Positif & Salmonella spp. \\
\hline 3 & Merah & Negatif & - \\
\hline 4 & Hitam & Positif & Salmonella spp. \\
\hline 5 & Hitam & Positif & Salmonella spp. \\
\hline 6 & Hitam & Positif & Salmonella spp. \\
\hline 7 & Hitam & Positif & Salmonella spp. \\
\hline 8 & Merah & Negatif & - \\
\hline 9 & Hitam & Positif & Salmonella spp. \\
\hline 10 & Hitam & Positif & Salmonella spp. \\
\hline 11 & Hitam & Positif & Salmonella spp. \\
\hline 12 & Hitam & Positif & Salmonella spp. \\
\hline 13 & Hitam & Positif & Salmonella spp. \\
\hline 14 & Hitam & &
\end{tabular}


I J A S Vol. 7 |Nomor 3 Edisi Desember 2017

\begin{tabular}{|c|c|c|c|}
\hline 15 & Merah & Negatif & - \\
\hline 16 & Hitam & Positif & Salmonella spp. \\
\hline 17 & Merah & Negatif & - \\
\hline 18 & Merah & Negatif & - \\
\hline 19 & Merah & Negatif & - \\
\hline 20 & Merah & Negatif & - \\
\hline 21 & Merah & Negatif & - \\
\hline 22 & Merah & Negatif & - \\
\hline 23 & Merah & Negatif & - \\
\hline 24 & Merah & Negatif & - \\
\hline 25 & Merah &
\end{tabular}

\section{Keterangan :}

Tanda (-) menunjukkan bukan koloni Salmonella spp.

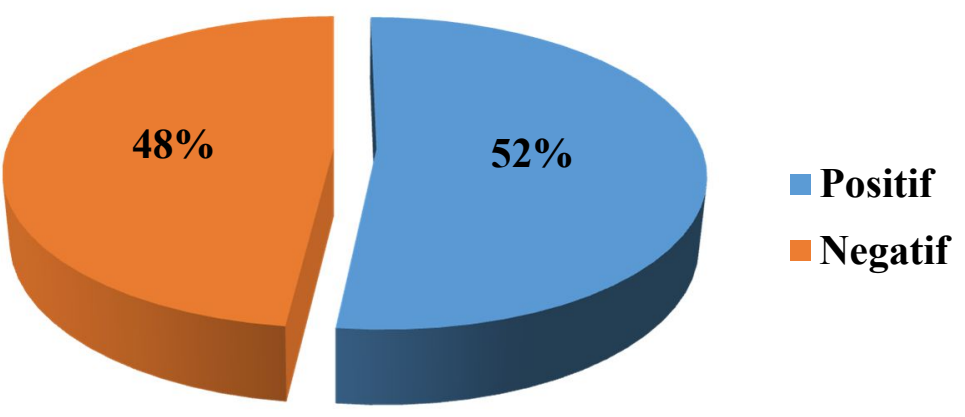

Gambar 1. Persentase hasil identifikasi Salmonella spp. pada feses sapi perah di Dusun Judeg, Desa Babadan, Kediri

Salmonella spp. memperbanyak diri dalam saluran pencernaan hewan pembawa, yang selanjutnya dikeluarkan melalui feses. Kontaminasi Salmonella spp. pada sapi perah bisa berasal antara lain dari pakan, air minum, tempat pembuangan feses, dan kondisi kandang yang kurang baik. Kontaminasi ini juga dapat mempengaruhi cemaran pada produk yang berasal dari peternakan (susu dan daging) dan lingkungan sekitar termasuk air sumur (Afriyani, 2016). Salmonella spp. adalah bakteri penyebab penyakit salmonellosis yang merupakan penyakit menular yang dapat menyerang hewan maupun manusia. Bakteri tersebut dapat menimbulkan berbagai macam manifestasi penyakit pada hewan dan demam enterik, serta gastroenteritis pada manusia. Salmonella spp. yang terbawa melalui makanan ataupun minuman akan memasuki saluran pencernaan. Di lambung, bakteri ini akan dimusnahkan oleh asam lambung, namun yang lolos akan masuk ke lumen usus. Bakteri ini akan melakukan penetrasi pada mukosa usus dan tinggal secara intraseluler dan akan berproliferasi. Ketika bakteri ini mencapai epitel dan IgA tidak bisa menanganinya, maka akan terjadi degenerasi brush border. Selanjutnya, di dalam sel bakteri akan dikelilingi oleh inverted cytoplasmic membran mirip dengan vakuola fagositik (Cita, 2011).

Berdasarkan hasil penelitian yang telah dilakukan di Dusun Judeg, Desa Babadan, Kediri, diperlukan usaha untuk mencegah kandang dan sapi perah dari cemaran bakteri. Usaha tersebut antara lain (Utami, 2012) :

1. Memperhatikan kandang sapi. Hal-hal yang perlu diperhatikan terhadap keadaan kandang adalah bentuk lubang angin (ventilasi) yang harus berfungsi dengan baik dimana udara bias masuk dan keluar dengan lancar dan hindarkan angin bertiup langsung kearah sapi perah, cahaya matahari diusahakan dapat masuk kedalam kandang, dan tempat penimbunan kotoran harus terletak 100 meter dari kandang.

2. Memperhatikan rumah peternakan. Rumah peternakan dibangun agar dapat memperhatikan leluasa kesegala arah dengan jarak dari kandang sekitar 30 meter.

3. Memperhatikan keadaan kesehatan sapi.

4. Memperhatikan kesehatan para peternak. Hal ini penting agar kontaminasi bakteri yang berasal dari peternak yang sakit dapat dihindari dan dikurangi.

5. Memperhatikan makanan yang berupa hijauan dan konsentrat sebagai pakan penguat dan air minum yang harus diberikan secara adlibitum (air selalu tersedia setiap saat pada tempat yang telah disediakan).

\section{SIMPULAN}

Sebanyak 13 sampel feses yang berasal dari 25 feses sapi perah yang ada di Dusun Judeg, Desa Babadan, Kediri positif mengandung Salmonella spp. Hal 
tersebut menunjukkan kurang baiknya sistem pengolahan peternakan yang ada di desa tersebut.

\section{DAFTAR PUSTAKA}

Afriyani, Darmawi, Fakhrurrazi, Manaf ZH, Abrar M, Winaruddin. Isolasi Bakteri Salmonella sp. pada Feses Anak Ayam Broiler di Pasar Ulee Kareng Banda Aceh. Jurnal Medika Veterinaria 2016; 10(1): 74-76.

Cita YP. Bakteri Salmonella thypi dan Demam Tifoid. Jurnal Kesehatan Masyarakat 2011; 10(1): 4246.

Direktorat Jendral Peternakan. Manual Penyakit Hewan Mamalia. 2014. Jakarta: Subdit Pengamatan Penyakit Hewan, Direktorat Kesehatan Hewan, Direktorat Jenderal Peternakan dan Kesehatan Hewan Kementerian Pertanian.

Hidayati YA, Benito AK, Harlia E. Analisis Jumlah Bakteri dan Identifikasi Bakteri pada Pupuk Cair dari
Feses Domba dengan Penambahan Saccharomyces cerevisiae.Jurnal Ilmu Ternak 2013; 13(2): 1-3.

Oscar G, Duarte G, Bai J, Elizabeth N. Detection of Escherichia coli, Salmonella sp., Shigella sp., Yersinia enterolitica, Vibrio cholerae, and Camphylobacter sp. Enteropathogens by 3 Reaction Multiplex Polymerase Chain Reaction. Diagnostic Microbiology and Infectious Disease 2009; 63: 1-9.

Ray B. Fundamental Food Microbiology. 2001. Edisi Ke2. Boca Raton Florida: CRC Press.

Staf Pengajar Fakultas Kedokteran UI. 2010. Buku Ajar Mikrobiologi Kedokteran. Tangerang: Binapura Aksara Publisher.

Utami PS. Penanganan Susu Segar Dalam Menjaga Kualitas Pasca Pemerahan. Skripsi. 2012. Program Pasca Sarjana Pengolahan Sumber Daya Alam dan Lingkungan. Universitas Bengkulu. 